\title{
Online Donation Behavior in Indonesia Through the Crowdfunding Site: A Study on the Instagram Account akitabisacom
}

\author{
Edy Prihantoro $^{1}$, Widiastiana Vista Wijaya ${ }^{2}$, Susilowati Dyah K. ${ }^{3}$ \\ Magister Communication Science, Gunadarma University, Depok Indonesia ${ }^{1,2,3}$ \\ \{edipri@staff.gunadarma.ac.id ${ }^{1}$, widiastiana.vw@staff.gunadarma.ac.id², susi@staff.gunadarma.ac.id ${ }^{3}$ \}
}

\begin{abstract}
Kitabisa.com, an Indonesian startup who is working on social enterprise. Crowdfunding can represent a fundamental transformation of the startup project, micro-enterprises and small and medium enterprises in accessing funding. To get the attention and action from reviews of those people, we need to create something that is compelling by building emotion into the media used such as Instagram, etc. To understand the success of an online donation project, research focuses on the various factors that influence behavior individuals in donating, such as trust, credibility and satisfaction, persuasion through website design, a factor demographic, socioeconomic, and other characteristic, donate online experience, awareness of donating. Given that the researchers investigated a variety of factors with a different focus, there is a need for a synthesis of different perspectives and the development of a systematic theoretical model to explain the behavior of individuals in donating online. The purpose of this study was to determine whether or not the relationship @Kitabisacom exposure Instagram account and project content donation to donate online behavior. The approach is quantitative research with the paradigm of positivism. The data collected was analyzed by Structural Equation Modeling (SEM) using Amos software. Based on the research results show that the latent variable frequency, duration, attention Instagram account access, the reputation of the initiator, the popularity of the project, the quality of project content, the credibility of the organization and donate online behavior is latent variables are valid and reliable. Frequency, duration, attention Instagram account access, the reputation of the initiator, the popularity of the project, the quality of project content, the credibility of the organization's positive influence on the behavior of online donating.
\end{abstract}

Keywords: online donation behavior; account exposure; content project donation

\section{Introduction}

According to the World Giving Index (WGI), in 2018 for the first time, Indonesia was on top in 20 of the most generous country of the world. WGI is an annual effort Charity Aid Foundation (CAF) to measure the level of generous citizens in a country to donate money, 
time, and helping people is not known. After finishing second in 2017, three scores giving individuals Indonesia largely unchanged [1]. From natural disasters that often occur, some public places to collect funds to contribute funds charitable donations of disaster victims by building global philanthropy and volunteerism. In general, the use of a charity box will be distributed from hand to hand or along the road, there is a place to give some of the money that is owned. However, the method is considered ineffective and inefficient. The traditional way to donate using a specific deadline for achieving the target value is determined. The information fundraising campaign did not reach the target of extensive bias in a short time. Through the charity box, accountability of the flow of funds is not accountable.

Fundraising activities (fundraising) through social networking is called crowdfunding. Through the online platform, to attract more donors, monitoring and evaluation of the program. The crowdfunding phenomenon is concrete evidence of the development of communication methods followed by the advancement of information technology. Crowdfunding is a fundraising activity carried out by collecting funds from the community with a small to moderate nominal for an interest that draws the attention of the community [2]. Crowdfunding is a collective financial approach that allows individuals in the community to agree to collect resources to fund a social activity of interest. The Canada Media Fund defines crowdfunding as the raising of funds through the collection of small contributions from the general public (known as the crowd) using the Internet and social media. Crowdfunding provides benefits to the community, especially in terms of fundraisers and funders [3]. People are waiting for activities like this, because the benefits can be directly enjoyed by the people without complicated rules and bureaucracy. In some previous studies, the theme of crowdfunding is more dominated by studies of crowdfunding concepts and business processes [4].

Kitabisa.com is one of the online donation sites with the most popular crowdfunding system in Indonesia. Based on the data obtained by researchers, there are several crowdfunding sites in Indonesia. The top 5 of those sites acording to alexa.com are: Kitabisa.com, Gandengtangan.org, Sharinghappiness.org, Akseleran.com, and Indogiving.com [5]. The concept of crowdfunding sites become attractive and potential. Through the website, the public is invited to make donations online in a variety of aspects, including social, educational, health, and so on. In 2017, crowdfunding through Kitabisa.com increased threefold compared to 2016. This is supported by a number of participants as many as 12,000 total collected funds amounting to Rp193 billion. Inversely, some crowdfunding sites have ceased to operate, namely Ayopeduli.com and Wujudkan.com. The closure of these services due to the acquisition of a percentage of fundraising success in every program is not increased. The crowdfunding phenomenon is concrete evidence of the development of communication methods followed by the advancement of information technology. Everyone can communicate, access, and provide information consistently on crowdfunding social projects or campaigns.

Given that the researchers investigated the various factors with a different focus, there is a need for a synthesis of different perspectives and the development of a systematic theoretical model to explain the behavior of individuals in donating online [6]. Therefore, researchers are interested in discussing exposure Instagram account and project content donation to donate online behavior in Kitabisa.com crowdfunding sites as research objects. The independent variable of the study is exposure to Instagram account and project content donation. While donating behavior online as the dependent variable. According to the data above, Kitabisa.com election as a research subject is the most popular crowdfunding website to rank first among 
other similar sites. It is interesting to study because Kitabisa.com always increase fundraising for campaign donations.

From the overall results above data, it can be concluded that the site Kitabisa.com crowdfunding that is trusted people of Indonesia and has been able to gain a lot of donors. Therefore, the overall purpose of this study is to analyze key variables that enable the creation of long-term relationships between donors, donors, and crowdfunding sites. Media is believed to have the power of large to affect the attitudes and behavior of human beings. Even the media is able to direct the community as what will be formed in the future. Media is able to guide and influence life in the present and the future. Exposure information or message occurs when a person is reading, watching, listening, and then the effects are either directly or indirectly so as to form in her perception of the information or message that reaches it. The effect will be seen in the attitude of the individual, whether to change the behavior or not. Exposure to media (media exposure) by Rosengren could be operationalized into the amount of time spent in different types of media, the content of the news media is consumed, and the connections between the individual media consumers to media content is consumed or the media overall [7].

In conducting the donation project, crowdfunding sites will display a message in the form of text, images, audio, video to improved attention mob. Based on the study conducted by Liu [8], donation project content is influenced by the reputation of the initiator, the popularity of the project, the quality of project content, and the credibility of the organization. Things were displayed by crowdfunding sites, as follows: the reputation of the initiator, the popularity of the project, the quality of project content, the credibility of the organization. Donating behavior is influenced by perceptions of individuals based on the values, understanding, and attitude. These factors are described as an intrinsic factor through the basic human desire to help others in need, such as responsibility and a desire for change and liabilities. In contrast, extrinsic factors are external factors that motivate and influence people to donate. Extrinsic factors include demographics such as age, gender, marital status, socio-economic, and the location has its own role [9]. Donating behavior is influenced by factors: attitude donate, social relations with the initiator of the project.

\section{Methods}

This study uses a quantitative approach. Quantitative research is research that aims to test a theory by means of elaborate hypotheses and collect data to support or refute these hypotheses [10]. Descriptive research is to describe the factors that influence behavior in Kitabisa.com to donate online. Based on the quantitative research methodology election, the strategy in conducting this study is a survey. The survey was conducted by distributing questionnaires via Google Form research online to followers Instagram account@Kitabisacom. In this study, the object is the influence of the exposure of @Kitabisacom Instagram account and project content towards online donation behavior, so this population is followers of @Kitabisacom's Instagram account which is 230,000 . To determine the sample size, researchers using the formula Slovin $[11,12]$. The error rate in this study was $5 \%$ or 0.05 . An estimated error rate of $5 \%$ is taken as the level of trust in the study was $95 \%$, or 0.95 , so the number of samples in this study were 400 samples. In this study sampling using sampling techniques nonprobability. The type of nonprobability engineering sample is purposive sampling. Purposive sampling is a sampling technique with specific considerations such as the respondent is Instagram account 
followers@Kitabisacom and respondents had to donate online through crowdfunding sites Kitabisa.com.

The method used is the Structural Equation Model (SEM). SEM is an inferential statistical analysis method focuses on the field of study analysis and interpretation of data to draw conclusions [13]. During its development, data processing for SEM analysis becomes easy with the help of some software (software) statistics, such as LISREL, AMOS, and SmartPLS. In this study, SEM analysis performed using AMOS software assistance. To measure the suitability of the model used then tested against a variety of factors goodness of fit. If the model is accepted, the investigator could consider a modification done to improve theoretical explanation models or goodness of fit. Modification of the initial model should be done after much deliberation assessed. If the model is modified, then the model must be estimated with separate data before the modified model is accepted. Measurements can be performed with the model modification indices. Value modification indices equal to the decline in the Chi-Square if the coefficient estimates.

\section{Results and Discussion}

\subsection{Validity and Reliability}

Validity test aims to determine whether the questions in the questionnaire representative or not. Test reliability is an index indicating a reliable measuring instrument. In this study, the test reliability using composite (Construct) reliability with a minimum cut-off value is 0.7 . Validity and reliability tests conducted by using confirmatory factor analysis on each of the latent variables, ie exposure Instagram account, the content of the donation project, and the behavior of donating online via AMOS program 22. Results research shows that exposure to Instagram account, the content of project donation, and donate online behavior are latent variables that are valid and reliable.

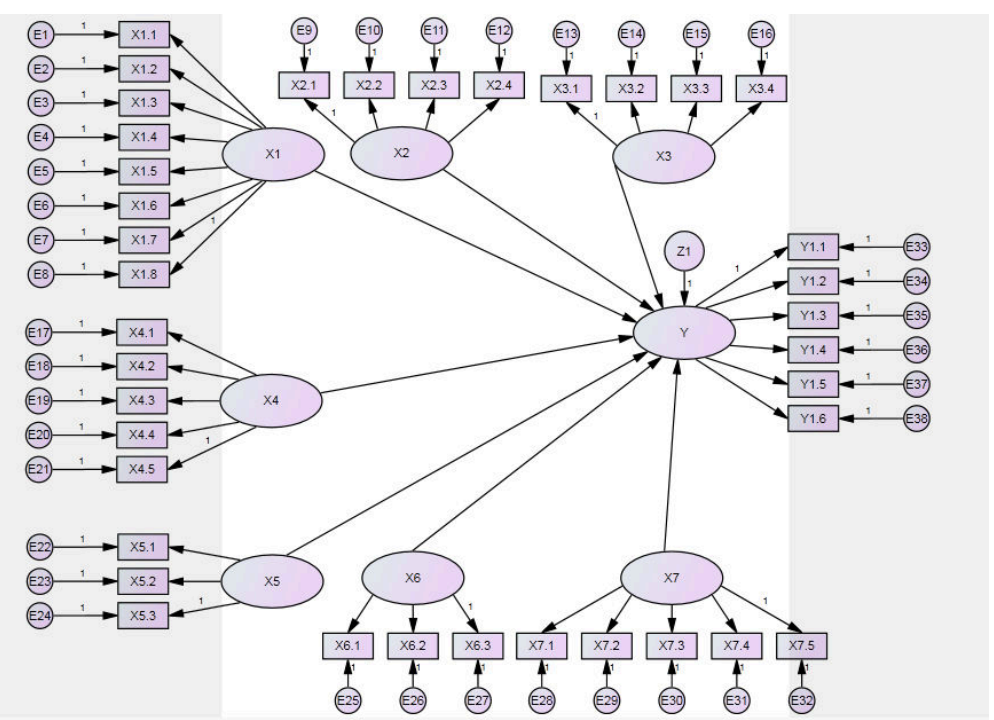

Fig 1. Relationship between Media Exposure of Instagram Accounts, Content Donation Project for Online Donation Behavior 
Table 1. Test results from Media Exposure of Instagram Accounts, Content Donation Project for Online Donation Behavior.

\begin{tabular}{|l|l|l|l|}
\hline \multicolumn{1}{|c|}{ Criteria } & \multicolumn{1}{c|}{ Cut-Off Value } & \multicolumn{1}{c|}{ The Calculation Results } & \multicolumn{1}{c|}{ Information } \\
\hline Chi-Square & $\begin{array}{l}\text { Expecte } \\
\text { d to be } \\
\text { small }\end{array}$ & 484.633 & $\begin{array}{l}X^{2} \text { with df }= \\
224 \text { was } \\
248.233\end{array}$ \\
\hline $\begin{array}{l}\text { Significanc } \\
\text { Probability }\end{array}$ & $\geq 0.05$ & .159 & Well \\
\hline RMSEA & & & Well \\
\hline GFI & $\leq 0.08$ & 0,037 & Well \\
\hline AGFI & $\geq 0.90$ & .834 & Well \\
\hline CMIN / DF & $\geq 0.90$ & 0.823 & Well \\
\hline TLI & $\leq 2.00$ & 1,448 & Well \\
\hline CFI & $\geq 0.95$ & 0.815 & Well \\
\hline
\end{tabular}

Based on Table 2 above shows that all meet eight criteria used to test the feasibility of the model, so as not to be modified. It states models to be accepted, which means there is a match between the model with data. Of a suitable model, it can be interpreted in the path coefficient. The coefficients of these pathways are hypothesized in this study. The results of path coeeficients tests are as follow:

a. Instagram account access frequency of positive and significant effect on the behavior of donating online. The above table shows that on the path marked positive coefficient of 0.155 with CR values of 3.457 and gained significance probability (p) of 0.00 is smaller than the significance level $(\alpha)$ which is set at 0.05 . Therefore, the frequency of account access to the Instagram direct effect on the behavior of 0.155 donate online, so every increase in frequency can be raised to donate online behavior of 0.155 .

b. Instagram account access duration of positive and significant effect on the behavior of donating online. The above table shows that on the path marked positive coefficient of 0.455 with CR values of 4.529 and gained significance probability (p) of 0.00 is smaller than the significance level $(\alpha)$ which is set at 0.05 . Therefore, the duration of the Instagram account access direct impact on the behavior of 0,455 to donate online, so every increase in the duration of the access can donate online behavior raises 0,455 .

c. Instagram account access attention of positive and significant effect on the behavior of donating online. The above table shows that on the path marked positive coefficient of 1.145 with $C R$ value by 5,750 and gained significance probability (p) of 0.00 is smaller than the significance level $(\alpha)$ which is set at 0.05 . Therefore, attention Instagram account access direct impact on the behavior of 1,145 to donate online, so every increase in attention can raise the access behavior of online donating 1,145 .

d. Reputation initiator of positive and significant effect on the behavior of donating online. The above table shows that on the path marked positive coefficient of 0.104 with CR values of 7.820 and gained significance probability (p) of 0.00 is smaller than the significance level $(\alpha)$ which is set at 0.05 . Therefore, the initiator reputation direct impact on the behavior of donating online at .104 , so every increase in the initiator can raise the reputation of donating online behavior 0.104 .

e. Popularity project of positive and significant effect on the behavior of donating online. The above table shows that on the path marked positive coefficient of 0.145 with CR values of 2.545 and gained significance probability (p) of 0.00 is smaller than the significance level $(\alpha)$ which is set at 0.05 . Hence, the popularity of the project direct 
impact on the behavior of 0,145 to donate online, so every rise in popularity of the project can donate online behavior raises 0,145 .

f. The content quality project of positive and significant effect on the behavior of donating online. The above table shows that of the marked positive path coefficient of 0,105 with a value of 3,743 and earned CR significance probability (p) of 0.00 is smaller than the significance level $(\alpha)$ which is set at 0.05 . Therefore, the quality of project content directly affects the behavior of 0,105 to donate online, so every increase in the quality of project content can donate online behavior raises 0,105 .

g. The credibility of the organization's positive and significant effect on the behavior of donating onlineThe above table shows that on the path marked positive coefficient of 0.125 with CR values of 3.564 and gained significance probability (p) of 0.00 is smaller than the significance level $(\alpha)$ which is set at 0.05 . Therefore, the credibility of the organization's direct impact on the behavior of online donating 0.125 , so every increase in the credibility of the organization can raise donating online behavior 0.125 . Kitabisa.com can be trusted by the community to raise and manage funds from the community and return it to the people who need it.

The results showed that of the total of the latent variables are frequency, duration, attention Instagram account access, the reputation of the initiator, the popularity of the project, the quality of project content, credibility can affect the behavior of online donating.

\subsection{Analysis of Linkages between Research and Theory SOR}

The classification of the S-O-R theory has a short-term and individualistic nature, so it is applied to intentional and unintentional effects. Implementation of that individual's response, in this case, a single message received by the individual will react individually $[14,15]$. Single message, namely exposure to use Instagram in this case@Kitabisacom account and contains information such as content donation project is the result of interaction between the user and the implications of the communication process that occurs, so that the reaction that implies nothing happens in an individual choice and is a behavioral reflex are donating behavior online. The stimulus given to the organism can be accepted or rejected. If the stimulus is received by the organism, then there is attention from the individual to the stimulus and are considered effective. Conversely, if the stimulus is rejected by the organism, it is not effective in influencing individual attention. In this study, @Kitabisacom Instagram account followers who were respondents of 400 people considered to have received stimulus from Instagram account@Kitabisacom form of exposure of intensity@Kitabisacom access Instagram account that contains the donation project.

The use of the S-O-R theory in this study proves that the behavior of donating online behavior is a reaction to the stimulus in the form of exposure and content of the donation project. Behavior is donating online media effects on individuals who started from exposure to messages@Kitabisacom Instagram account. Stimulus received and got the attention of the organism via Instagram account followers@Kitabisacom attention measurable indicators. Followers Instagram account @Kitabisacom know fully and clearly to upload delivered. The content donation project is one of the stimuli that be the deciding factor against the given effect. This form of reputation initiator the project, the popularity of the project, the quality of project content, and the credibility of the organization. According to the results of exposure above that, the entire response provides answers to agree to a statement of each indicator. The stimulus reception understood by the organism, causing a certain effect on the individual. 


\section{Conclusions}

In accordance with the conclusions obtained from the above results, the researchers seek to provide advice. Kitabisa.com expected from this research can maintain the quality of content submitted through Instagram and transparency in the use of funds to each project donations. Said speed messages through the comments field has been done by @Kitabisacom Instagram account, but can be added to the sentence that can draw intension prospective donors to see more information on the official website belonging to Kitabisa.com. Instagram account followers @Kitabisacom role is crucial for the sustainability of Kitabisa.com, because of the results of this study indicate that the majority of donating as much as 4-7 times a month. The critical attitude is required to submit a response to the intensity of the information submitted by Kitabisacom. From all owned Kitabisa.com social media, Instagram account obtained many responses as like and comment on uploads. The result of this research is closely related not only to the crowdfunding site Kitabisa.com and prospective donors, but the donations project initiator. Researchers observed that the role of the initiator of the project has not been a significant donation to the content uploaded by Instagram account @ Kitabisa.com. Through this research, the initiator of the project is expected to contribute a donation in person at the comments field of the upload, so that prospective donors who are followers can find out and get to know more closely with the organizers of the project.

\section{References}

[1] Charities Aid Foundation. CAF World Giving Index: A Global View of Giving Trends. 2018

[2] Ordanini. Crowdfunding: Transforming Customers Into Investors Through Innovative Service Platforms, 2009.

[3] G. Koren. A History of Crowdfunding. Retrieved from Crowdsourcing and Crowdfunding - The Industry. Rerieved from: http://www.crowdsourcing.org/document/ahistory-of-crowdfunding/3169, 2010.

[4] P. Belleflamme, T. Lambert, A. Schwienbacher, A. "Crowdfunding: Tapping The Right Crowd". Journal Bussiness Venture, Vol. 29, No. 5, pp. 585- 609, 2014.

[5] www.alexa.com, January, 22019.

[6] J. Feller, R. Gleasure, S. Treacy, S. 2013. Crowdfunding: Past Research, Future Directions. European Conference on Information System. Netherlands: Utrecht, 2013.

[7] C. Liu. Finance strategies for medium-sized enterprises: Fintech as the game changer. In M. Vemic (Ed.). Strategic Optimization of Medium-Sized Enterprises in the Global Market, pp. 162-184. Hershey: IGI Global, 2018.

[8] A. Lukkarinen, J. E. Teich, H. Wallenius, J. Wallenius, "Success drivers of online equity crowdfunding campaigns," Decis. Support Syst., Vol. 87, pp. 26-38, 2016.

[9] S. Sura, J. Ahn, O. Lee. Factors influencing intention to donate via social network site (SNS): From Asian's perspective. Telematics and Informatics Vol. 34, No. 1, pp. 164176, 2017.

[10] J.W. Creswell. Research Design Pendekatan Kualitatif, Kuantitatif dan Mixed. Yogyakarta: Pustaka Pelajar, 2013. 
[11] R. Kriyantono. Teknik Praktis Riset Komunikasi. Jakarta: Kencana Prenada Media Group, 2014.

[12] Morissan. Metode Penelitian Survei. Jakarta: Kencana Prenada Media Group, 2017.

[13] U. Silalahi. Metode Penelitian Sosial Kuantitatif. Bandung: PT Refika Aditama, 2017.

[14] D. Mulyana. Ilmu Komunikasi: Suatu Pengantar. Bandung: Simbiosa Rekatama Media, 2008.

[15] W.J. Severin, J.W. Tankard. Teori Komunikasi: Sejarah, Metode, dan Terpaan di Dalam Media Massa. Jakarta: Kencana Prenadamedia Group, 2014. 